\title{
1. Off or on field? The multilevel parliamentary field of EU external relations
}

\section{John Erik Fossum and Guri Rosén}

The purpose of this chapter is to discuss the issue of democratic control and accountability in the realm of European Union (EU) external relations. Legislative assemblies are key instruments in ensuring democratic control. This chapter places particular emphasis on the multilevel system of legislatures in the EU. The EU has developed a distinctive structure of legislative relations that shapes its ability to exercise democratic control and accountability of external relations.

EU external relations are profoundly affected by the fact that Member States have not abrogated their sovereignty, but have come together to pool it and share it in a common set of institutions. That affects the ways in which domestic and foreign relations are handled within the multilevel EU context. It also shapes legislative relations in the multilevel EU. A distinctive feature of legislative relations within the EU context is that they connect parliaments across levels of governing. The system of inter-parliamentary relations holds traits that resemble a multilevel parliamentary field (MLPF) (Crum and Fossum 2009, 2013). By MLPF we mean that parliamentary systems share certain structural similarities and are connected across states and levels of governance. The issue is whether or the extent to which the EU's MLPF incorporates EU external relations. We consider how extensive the incorporation is and what the democratic implications might be.

In the next section, we outline core features of the EU polity in order to show how EU external relations are structured. Thereafter, we spell out in more detail how the various aspects of EU external relations are organized. Particular emphasis is placed on how parliaments control and scrutinize these relations. In the final section, we discuss democratic implications. 


\section{THE EU POLITY AND HOW IT STRUCTURES EXTERNAL RELATIONS}

The EU's external relations cover a broad range of different policy areas, and this range has expanded and intensified since the end of the Cold War. Some of the relations contain a mix of internal and external components, such as the Common Fisheries Policy, the EU's Energy Policy and the policies that fall under the area of Justice, Freedom and Security. Others solely address relations with third parties, such as the EU's Common Commercial Policy and its development policy, as well as its Common Foreign and Security Policy (CFSP), which also encompasses security and defence issues under the Common Security and Defence Policy (CSDP). The EU has conducted a large number of military and civilian operations, it speaks with a single voice in international trade negotiations, and it manages the world's largest development budget. There are however some important variations in the EU's competence. These variations have ramifications for executive-legislative relations.

In order to understand EU external relations, we need to pay attention to the nature of the EU polity. External relations, and particularly security and defence policies, are essential for self-determination; but there is a fundamental difference between the external relations of an international organization and the external relations of a sovereign state. With regard to the former, the international organization's external relations are profoundly shaped by the Member States, which retain ultimate control and structure external relations. With regard to the latter, external relations are generally the preserve of the central state level.

The EU is a contested entity that does not neatly fit with either category - international organization or sovereign state. Some analysts depict it as an international organization, but they readily acknowledge that it is a very special kind of international organization. Others depict the EU as a distinct form of organization, which embodies state-type features. The EU is not a state, but the Member States lend it a measure of stateness. ${ }^{1}$ That takes place without the EU transcending these Member States. The Member States, as noted above, share and pool sovereignty in a set of common EU-level institutions (Hooghe and Marks 2015; Fabbrini 2015). The EU stands out from all federal-type entities in the sheer magnitude

1 Genschel and Jachtenfuchs (2014) have shown how EU integration has moved into important core state powers. These are structured along the lines depicted here. 
of Member State control of EU-level institutions. ${ }^{2}$ Two of the EU's most central institutions, the European Council and the Council of Ministers, are composed of representatives of the Member States. The fact that the EU is a composite of Member States has direct bearings on the nature of EU external relations, and impresses on us the need to bring Member States directly into the equation.

When the states came together to form the EU as a Union of states and citizens, they allowed a significant portion of their external relations to be domesticated and organized along lines similar to those we associate with states. The establishment of the Common Commercial Policy (an exclusive EU competence), for instance, was an immediate consequence of the creation of a customs union. For the Member States, that meant that their traditional external relations became tracked along two lines: a new distinction emerged between the relations they developed with their fellow EU (and to a large extent European Economic Area) members on the one hand and the relations they developed with the non-members, or the rest of the world, on the other.

This distinction does not resemble the distinction between domestic and international relations that we find in traditional states. The EU's Member States relate to each other in manners similar to those we find internally among sub-units in federations as well as in manners similar to those that structure relations among sovereign states in the international realm. ${ }^{3}$ Member States have retained their foreign policy apparatuses, which operate in EU-external and EU-internal matters. Parliamentary oversight and control are organized along the lines of these EU divisions rather than along the traditional lines of domestic and international relations that we are familiar with from states.

In the EU context, as we will see, the critical determinant pertaining to democratic scrutiny and control relates to the degree to which an issuearea is communitarized, not whether it is EU-internal or external. Thus, since some issue-areas are not communitarized, the system of democratic scrutiny and control is considerably less developed in those issue-areas, notably security.

2 This is not only a matter of direct Member State representation in the EU institutions; it is also one aspect of the integration process. The so-called new intergovernmentalists argue that an important aspect of the EU's development post-Maastricht is integration without supranationalism. See Bickerton et al. (2015).

3 Sub-units in federations and EU Member States confer exclusive competences on the central institutions or they share competences with the central institutions. 
The EU is a complex system which consists of two distinct integration tracks that reflect and uphold the two different manners in which states structure their external relations. Historically the core of this system is the European Community (EC), whose institutional operations rely on the so-called 'Community Method'. That is based on an independent European Commission with the exclusive right to present legislative and policy proposals. These are adopted by the European Parliament (EP) and the Council; and the Court of Justice of the European Union (CJEU) maintains the institutional balance (Majone 2005, p. 44). It is situated in a unipolar federal-type structure (with some semblance to the German federal system) that issues authoritative commands. The system rests on the core principle that underpins the Community architecture, namely that action addressed at common problems entails the adoption of action norms that have been decided in common on the basis of legislative input from the Commission, and these are to be uniformly applied to all the Member States. The doctrines of supremacy and direct effect are meant to ensure that these are encoded or transformed into the legal arrangements of the Member States.

The other track has its roots in the Maastricht Pillars II and III and operates in accordance with the so-called 'Union Method'. Under this more intergovernmental system, the Commission plays a far less prominent role. In contrast to the Community Method, under the Union Method, the Commission has no exclusive right of initiative; the Council is assumed to decide by unanimity and there is generally no role for the CJEU. In contrast to the Community Method where the EP is a colegislator, under the Union Method the EP is only consulted or informed.

This complex system is one that produces a rather fragmented EU executive, with executive tasks distributed across a number of different institutions that span these two tracks. All three bodies - Commission, European Council and Council - carry out de facto executive functions. Further, the Council has both executive and legislative tasks. The division of executive and legislative tasks across the EU institutions is therefore quite ambiguous (Sjursen 2011; Cross 2013).

At the same time, the EU is marked by considerable fusion of levels (Wessels 1997). EU Member States are far more directly involved in the activities at the EU level than is the case in all other federal-type systems. Member States thus have a lot of control of what goes on at the EU level. The element of direct control is particularly strong in sensitive areas such as foreign and security policy where Member States are the key actors.

This section has shown how the complex and composite two-tracked nature of the EU polity shapes its external relations. It is this distinction and not the distinction between EU internal and external affairs that 
shapes and conditions parliamentary involvement in EU matters. The distinction reflects the different manners in which the Member States help shape the conduct of the institutions at the EU level; the obvious implication is that we cannot analyse the realm of EU external relations without taking the Member States explicitly into account.

\section{THE MULTILEVEL EU PARLIAMENTARY DIMENSION AND EXTERNAL RELATIONS}

From the EU's inception, parliaments - at all levels - had to catch up with an integration process driven by executives and experts (Crum and Fossum 2013). We may identify three types of parliamentary catching up: a) the development of the European Parliament; b) increased national parliament involvement (in relation to own institutions and in relation to EU institutions); and c) increased inter-parliamentary interaction and involvement across levels of governance.

We will show that the process of parliamentary catching up reflects or mirrors the pattern of EU integration that has proceeded further in the realms of the internal market and flanking areas than in fiscal policy and foreign and security policy. What is more, it also mirrors the two-tracked system described above. Lack of space compels us to confine the analysis of parliamentary catching up to two important aspects of external relations, but the patterns we uncover also extend across other aspects of external relations.

With regard to a) - the development of the European Parliament's powers - the difference between its role in the EU's Common Foreign and Security Policy on the one hand and its role in EU international trade policy on the other illustrates the two-tracked structure described above.

External trade policy has been an exclusive competence of the Union ever since the Rome Treaty. The EU's power in and through trade has increased in line with enlargements and the process of integrating the internal market (Nicolaïdis and Meunier 2005). Trade is the area of EU external relations where the Member States are the most integrated (Woolcock 2012).

With the Lisbon Treaty, the EU's competence includes trade in goods, services and commercial aspects of intellectual property, as well as foreign direct investment. The general picture pre-Lisbon was that exclusive competence entailed that the Commission would propose the mandate for negotiation and the Council would alter and approve it, after which the Commission would negotiate on behalf of the entire Union. When the talks were done, the Council would decide by Qualified Majority Voting 
(QMV). If, however, trade agreements encompassed areas that did not fall under EU exclusive competence, they had to be ratified nationally. That required unanimity in the Council, and in negotiating such agreements both the Commission and the Member States could represent the Union (Adriaensen 2017).

The Lisbon Treaty also marks a considerable change in terms of executive-legislative relations. Before the entry into force of the Lisbon Treaty, the EP was hardly involved in trade policy-making, except for large multilateral agreements such as those of the World Trade Organization (WTO). Moreover, the EP's right to consent was contested. It had to argue case by case why parliament should obtain a say on international agreements, and the Council did not always agree (Rosén 2017). At the Nice Intergovernmental Conference (IGC), the suggestion that the EP's powers should be formally enhanced was not backed by any Member State (Krenzler and Pitschas 2001, p. 312). Thus, the changes emanating from the Convention on the Future of Europe brought a small revolution to the area of trade, where national and European trade technocrats had been accustomed to working in comfortable isolation from inquisitive politicians (Rosén 2016). First, external trade policy was to be implemented through European legislation. As a result, trade became subject to the Ordinary Legislative Procedure. This meant that the EP became a co-legislator, together with the Council, on regulations regarding for instance trade-defence or anti-dumping measures. Second, the EP now also has to give its consent whenever the EU concludes a trade agreement. However, the EP's new powers extend well beyond the area of trade and apply to nearly "virtually any international agreement ... of any significance" (Corbett 2012, p.249). Finally, the Commission is required under the Treaty to report regularly to the EP about international trade negotiations, during the entire negotiation process.

Although one can debate to what extent the CFSP is actually intergovernmental, there is no doubt that decision-making procedures cater to the continued dominance of the Member State governments. The 'limited roles' played by supranational institutions is held to be a further sign of "the dominance of Member State governments" (Giegerich and Wallace 2010, p.442). This means that the CFSP is largely outside the jurisdiction of the Court of Justice, and that the European Parliament's formal role is informational and consultative. Although the CFSP has developed both rapidly and extensively, the EP's treaty powers have remained the same since Maastricht. According to Article 36 TEU, the EP is to be informed and consulted on the main choices and basic principles of the policy, can ask questions, and hold debates about the CFSP twice yearly. Because expenses on the CFSP (except for military operations) 
are regarded as non-compulsory, it allows the EP the right to allocate and increase expenditure (Corbett et al. 2005, p. 251). This gives the EP a certain amount of influence over how the Community spends its funds on foreign policy issues. Thus, the EP has been quite successful in using the CFSP budget as a lever to establish rules and procedures for information and control. ${ }^{4}$ Still, the involvement of the EP is largely based on informal procedures and practices (Rosén 2015).

A common depiction of $b$ ) - the role of national parliaments in the area of the CFSP - is that they are rarely able and often not willing to influence or scrutinize EU foreign policy (Bono 2005; Gourlay 2004; Peters et al. 2010). Parliaments are generally less involved in the conduct of external relations, and the area of security and defence policy, in particular, is regarded as an executive prerogative. The extent of powers that national parliaments have in the case of the CFSP vary widely, although Huff has shown that supervision is not necessarily dependent on formal authority, but connected to the willingness and ability to scrutinize their own governments' activities (2015, p.407). In the context of trade, national parliaments were largely sidelined, first by the increasing centralization of EU trade policy and second by the empowerment of the EP (RoedererRynning and Kallestrup 2017). There are indications that the national subservience to the executive might be changing, however, particularly in the wake of the debacle over the Transatlantic Trade and Investment Partnership (TTIP) between the EU and the US, but also in the case of the Comprehensive Economic Trade Agreement (CETA) between the EU and Canada. When international agreements are so-called mixed agreements - i.e. they encompass areas of shared competence between the EU and the Member States - they have to be decided according to national constitutional rules. CETA, it was decided, was a mixed agreement, and TTIP in all likelihood would have been one. Roederer-Rynning and Kallestrup claim to have identified a growing role of national sovereignty that inter alia has manifested itself in increasing parliamentary assertion in the area of trade. Jančić describes how "many parliaments adopted a proactive approach seeking to shape their executive's trade policy" (2017, p. 208), but also that parliamentary involvement is conditioned by factors such as "political culture, tradition of scrutiny of EU affairs, and system of government" (ibid., p. 212).

At the same time, it is important to note that national parliament involvement has become increasingly coordinated. That may serve as

4 CFSP agreements are exempt from the EP's right to consent to international agreements (Article 218(6) TFEU). 
a potential compensatory mechanism for national parliaments' lack of power or resources, in the sense that it may reinforce their efforts at holding their executives to account (Wouters and Raube 2012). There are, and have been, various bodies that bring together parliamentarians working on foreign policy issues. Some are parliamentary assemblies, such as the one affiliated with NATO (see also Selden and Oehman, Chapter 12 this volume); others have taken the form of conferences, such as the Conference of Foreign Affairs Committee Chairpersons and the Conference of Defence Affairs Committee Chairpersons. When the EU established the European Security and Defence Policy in 1999 it gradually assumed the tasks of the Western European Union (WEU). In taking over the 'Petersberg tasks', all operational functions had been transferred to the EU, and the WEU was dissolved in 2011 (see also Fromage, Chapter 10 this volume). A corollary question that surfaced as a result of this development was what type of body - existing or not - would adopt the rights and responsibilities of the Parliamentary Assembly of the WEU. The WEU parliamentary assembly suggested a bicameral body consisting of MEPs and MPs, but the idea did not gain support (Marschall 2008). Finding a replacement proved difficult as parliamentarians could not agree among themselves - neither on the composition nor on the tasks of the new body. In the words of Wouters and Raube: "no overall consensus was reached because of the differing conceptions of what kind of parliamentary cooperation should be sought in the first place" (2012, p. 157).

This debate continued in the wake of the entry into force of the Lisbon Treaty, which greatly enhanced the role of national parliaments. Article 10 of the Protocol on the Role of National Parliaments in the European Union, attached to the Lisbon Treaty, states that inter-parliamentary conferences may be organized "in particular to debate matters of common foreign and security policy, including common security and defence policy". A long debate ensued about the best way of organizing such a conference. National parliamentarians were described as "anxious to ensure that inter-parliamentary cooperation on the CFSP/CSDP does not impinge in any way whatsoever on their own powers of scrutiny vis-à-vis their governments" (Caballero-Bourdot 2011, p. 42). Thus, many preferred a body akin to the Conference of Parliamentary Committees for Union Affairs (COSAC), which would bring together members of foreign affairs committees (ibid.). In other words, they wanted to be able to meet, but not to confer too much concrete power to that gathering. The European Parliament, on the other hand, was afraid that such a structure would undermine its own position, and in a resolution on the matter emphasized that "the European Parliament is a source of democratic legitimacy for the CFSP and the CSDP" (European Parliament 2011). 
These different positions not only reflect the differences in the selfunderstanding of parliamentarians at the different levels, but also illustrate the interwoven character of the levels of decision-making, scrutiny and control. These developments show that when we talk about national parliaments and national parliamentary involvement, we need to consider how each national parliament is involved as an individual body, as well as how national parliaments may operate as a collective of parliaments. When this collective spans levels of governing encompassing the EP, we may discuss whether what is emerging might be subsumed under the label multilevel parliamentary field.

With regard to c) - inter-parliamentary interaction across levels - two important issues arise. One pertains to the scope of inter-parliamentary interaction, the other to the presence or absence of the EP. Our claim is that we see traits of a multilevel parliamentary field in the area of EU external relations. Multilevel parliamentary field, as noted above, refers to how parliamentary systems share certain structural similarities and are connected across states and levels of governance. The main rationale for discussing inter-parliamentary interaction along the lines of multilevel parliamentary field is because it provides us with a useful heuristic device to consider the nature and density of parliamentary interaction across levels: European, national and regional (especially in federal Member States where regional or Land parliaments play an important role). Parliamentarians and parties share the same overarching function, namely that of representing their citizens. In addition, they are linked and interact across institutions and levels of governance. It is important when applying the notion of multilevel parliamentary field to the EU that what we find in the EU is a somewhat uneven and loosely composed field. There is great diversity across parliaments in the EU, and the field is marked more by informal than formal horizontal mechanisms wherein political parties also play a role. ${ }^{5}$ This is a lopsided and democratically deficient structure. Nevertheless, the notion of MLPF enables us to include what in the EU has emerged as an increasingly important 'horizontal' (meaning same level of governance) and 'triangular' (meaning relations among parliaments across levels) component to the activity of parliaments. Since the Treaty of Amsterdam we see that national parliaments have become increasingly oriented towards each other through COSAC and other means of inter-parliamentary interaction. Parliaments in the EU increasingly orient themselves towards each other and copy, emulate and learn from each other. There is also a mechanism that involves them in a collective capacity

5 See the various contributions in Crum and Fossum (2013). 
in EU-level decision-making, namely the Early Warning Mechanism (EWM).

The system of inter-parliamentary interaction is most clearly manifest in areas of shared competence (this is characteristic of the EWM). These encompass those areas where Member States' policies are EU domesticated. Conversely, it is in the realm of EU external relations that the EU's multilevel parliamentary field is the least developed. As we have shown, formally speaking, EU external relations are marked by a strong element of EU own competence (with the EP playing a central role), as well as a strong element of Member State retention of own competence (with national parliaments playing the central role). At the same time, we have also shown that the increased role and presence of the EP as well as of national parliaments in EU affairs has increased the scope and range of contacts among parliaments across levels of governance.

There are explicit efforts to coordinate the work of the two main parliamentary levels - European and national - also in the realm of external relations. The Interparliamentary Conference on the CFSP, launched in 2012 , provides an arena where parliamentarians working on the EU - and Member State - levels can meet and exchange information. ${ }^{6}$ As described above, the model for this Interparliamentary Conference was COSAC, which means that it brings together foreign affairs committees from Member State parliaments, as well as from the EP. Its main aim, as stated in the Rules of Procedure, is to "provide a framework for the exchange of information and best practices in the area of CFSP and CSDP". In addition, there are numerous informal contacts between MPs and MEPs from the same national parties. Peters et al., for instance, describe how contacts between parliamentarians extend beyond the conference meetings, constituting networks that facilitate the exchange of information across borders. This information can subsequently be used to 'improve MPs' position vis-à-vis their government" (2013, p. 121).

However, the vertical cooperation between national parliaments and the EP has proved to be difficult in external relations, as indicated above. Based on the debate that arose after the WEU parliamentary assembly was dismantled, Herranz-Surrallés asks whether the relationship between the national and the European level in foreign and security policy is best described as a "multilevel parliamentary battlefield". She argues that "imbalances between formal constitutional authority and the actual

6 The Interparliamentary Conference replaced the Conference of Foreign Affairs Committee Chairpersons and the Conference of Defence Affairs Committee Chairpersons. 
parliamentary capital that parliamentarians enjoy in a given field tend to generate conflict over authority between parliamentary levels, thus disrupting inter-parliamentary cooperation" (2014, p. 958). But, whereas conflicts clearly emerge, there are norms, roles and identities that shape and condition conflicts as well as paving the way for cooperation.

Whether parliamentarians at the EU level should be the ones responsible for guarding the preferences of EU citizens and holding decision-makers to account is a matter of continual debate. In line with the view that EU foreign policy should be intergovernmental, many hold that democratic legitimacy in the area should derive from national parliaments and not the EP. The debates that were taking place during the European Convention illustrate how unsettled this issue is. ${ }^{7}$ The working group on the role of national parliaments underlined that the two levels of parliaments were not in competition. Nevertheless, during the debates some speakers argued for more involvement of the EP; others contended that "democratic legitimacy came from national parliaments" and that oversight, particularly in the area of security and defence, is a job for national parliamentarians (European Convention 2002). It is not only national parliaments that are critical of the EP's powers in foreign policy. During debates about whether or not to demand more powers in the CFSP for the EP there are examples of MEPs taking the word to argue against the EP's involvement. For instance, during a debate about the EP's access to sensitive Council documents in the area of security and defence, MEP Titford (EPP), stated: "despite attempts to make them otherwise, security and defence are matters for the European Council" (EP Plenary, 22 October 2002). Interestingly, we have recently seen similar arguments surface in the trade debates in Strasbourg. During the plenary debate on the Comprehensive Economic Trade Agreement between the EU and Canada (see also Jančić, Chapter 28 this volume), several MEPs claimed that the EP's vote does not suffice as a legitimator of the EU's commitments in CETA, also throwing into doubt the mandate of the Commission to negotiate on the Union's behalf (EP Plenary, 15 February 2017). Although there were several arguing against this view as well, tensions were accentuated by efforts of Belgium's regional parliament in Wallonia to impede the signing of the agreement, as well as by the news that French MPs have made an appeal to the French constitutional court to stop CETA.

Two key points summarize this brief overview of parliamentary efforts at catching up with an integration process driven by executives and

7 The Convention produced the now defunct Constitutional Treaty. Much of the substance of that was subsequently incorporated in the Lisbon Treaty. 
experts. The first is that there is an ongoing struggle in the realm of external relations over who has the legitimate right to act as representatives of the EU citizenry. This issue cuts to the very heart of the constitution of the EU as a polity. The second is that this struggle is part of a broader process, which links parliaments more closely together. There is no assurance that this process will foster consensus; increased proximity may raise conflict as well as collaboration.

We have already indicated that some of the sources of conflict pertain to democratic and legitimacy considerations. It is to those aspects that we turn in the last part.

\section{CONCLUDING DISCUSSION ON DEMOCRATIC IMPLICATIONS}

The complex nature of EU external relations (relating to the EU's twotracked institutional structure) coupled with uncertainty about the EU's subsequent direction compels us to consider democratic implications with reference to two qualitatively different models of inter-parliamentary relations. We deem these, respectively, a learning structure and a decisionmaking structure. ${ }^{8}$ Even if both of these models are about multilevel inter-parliamentary relations and as such refer to the MLPF (and not for instance horizontal inter-parliamentary cooperation among national parliaments only), the two models refer to two qualitatively different ways of organizing multilevel inter-parliamentary relations.

The first 'learning structure' model conceives of the MLPF as a deliberative structure bent on learning and emulation, and highlights how parliaments in the EU increasingly consider each other as part of their operating environment and copy, emulate and learn from each other. Such patterns of learning manifest themselves in the adoption of best practices of parliamentary scrutiny, decision-making, internal organizing, relations to citizens, etc. A key aspect of such a learning structure is that learning is voluntary. Another important point is that there are numerous conveyors of information, channels or forums through which learning can take place. Core components are available sources of knowledge, meeting places, forums for exchange of information about arrangements and best practices, and some element of structure and consistency to the patterns

8 These are briefly presented in Fossum (2017). Benz (2017) discusses the merits of a wide range of configurations. Neither study applied them with explicit reference to the realm of EU external relations. 
of interaction. In addition, a learning structure can encourage parliaments to operate in such a manner as to provide external checks on each other. That may serve an important democratically corrective function: to prevent deviations through moral suasion, parliamentary investigations, parliamentary debates, personal contacts and access to external sources of information when their own governments withhold it from them (Peters et al. 2013).

From a democratic perspective, the two core components of the learning structure - adopting best practices and preventing deviations - can be configured as a system of multilevel inter-parliamentary relations without abrogating or deviating from the conventional - vertical - manner in which democratic authorization and accountability unfold. Within the 'learning structure' model, horizontal relations in no way interfere with the critically important role of vertical relations, connecting parliaments and citizens, which figure centrally in the manner in which we are accustomed to think of authorization and accountability.

We see elements of this learning structure in the field of EU external relations. At the same time, the weak role played by the EP in CFSP testifies to significant constraints pertaining to lack of transparency coupled with the relative absence of a central parliament that can 'orchestrate' and coordinate actions in the field.

External relations under CFSP can easily 'veer off the parliamentary field'. The Union Method is not very conducive to the fostering of a multilevel parliamentary field. The Community Method is far more so. Here inter-parliamentary relations are denser, more compelling, and mix horizontal and vertical dynamics. Since EU external trade for instance is subject to the Community Method, it is necessary to analyse that under an alternative field model that we here discuss along the lines of a 'joint decision structure' (Fossum 2017). In such a structure levels of governing are tightly interwoven, and decision-making processes at one level of governing include actors from other levels of governing. Such a configuration harbours a strong horizontal and 'diagonal' logic in that parliaments on different levels interact with each other's core activities, especially through the inclusion of lower-level parliaments in decision-making processes at the central level.

A joint decision structure configuration affects legislative-executive relations at all levels (wherein national parliaments intervene in EU decision-making processes, with bearings on legislative-executive relations at the national level). Such a configuration could break with democratic orthodoxy in the sense that it would no longer simply operate along vertical lines of authorization and accountability, but would raise questions pertaining to how we should conceive of democratic authorization and 
accountability. If the structure is configured such that parliaments react as much to the horizontal inputs from other parliaments (and actors in the system) as to the vertical inputs from citizens, an important dynamic of within-puts would operate alongside the type of input that we typically associate with upstream legitimation. It is important to note that the peculiar democratic challenge here is that it is parliaments taking cues from other parliaments.

Whereas it is well known that all parliaments react to other institutions in the political system, in the systems we are familiar with they do so according to a division of labour where a parliament is recognized as having a special responsibility - and a special authorization - to speak on behalf of the citizens, i.e. its constituency. Such a structure of authorization and accountability is essentially vertical. When a system is upset by horizontal within-puts, citizens may no longer know who represents them and in what respect they do so. The issue is then whether a non-centralized system in which the parliaments coordinate and cooperate in a joint decision structure can be accountable at all.

The EU under the Community Method is moving towards a joint decision structure. That appears to include the area of external trade, even if large parts are exclusive EU competence. Thus, we find that the EU has traits of both field configurations - as a highly deficient learning structure in the area of CFSP and as a form of fledgling joint decision system under external trade. A properly functioning multilevel parliamentary field presupposes a central parliament that can serve as a 'field coordinator' as well as a reference for all citizens.

Thus, one could argue that the EU's experimenting with new forms of configuring representative relations hinges on developing an adequate role for the EP. There is an urgent need for systematic thinking of the democratic and legitimacy implications of such experiments. Attempts to substitute the EP with national forms of collaboration would be akin to throwing the democratic baby out with the bathwater.

\section{REFERENCES}

Adriaensen, J. (2017) National Administrations in EU Trade Policy: Maintaining the Capacity to Control. Basingstoke: Palgrave Macmillan.

Caballero-Bourdot, C. (2011) Interparliamentary scrutiny of the CFSP: avenues for the future. Occasional Paper no. 94. Paris: EU Institute for Security Studies.

Benz, A. (2017) Patterns of multilevel parliamentary relations: varieties and dynamics in the EU and other federations. Journal of European Public Policy. 24(4), 499-519.

Bickerton, C., Hodson, D. and Puetter,U.(eds)(2015) The New Intergovernmentalism: 
States and Supranational Actors in the Post-Maastricht Era. Oxford: Oxford University Press.

Bono, G. (2005) National Parliaments and EU External Military Operations: Is there Any Parliamentary Control? European Security. 14(2), 203-29.

Corbett, R. (2012) The evolving roles of the European Parliament and of national parliaments. In: Biondi, A., Eeckhout, P. and Ripley, S. (eds) EU Law after Lisbon. Oxford: Oxford University Press.

Corbett, R., Jacobs, F. and Shackelton, M. (2005) The European Parliament. 6th ed. London: John Harper Publishing.

Cross, M. (2013) Security Integration in Europe: How Knowledge-Based Networks Are Transforming the European Union. Ann Arbor: University of Michigan Press.

Crum, B. and Fossum, J.E. (2009) The multilevel parliamentary field: a framework for theorising representative democracy in the EU. European Political Science Review. 1(2), 249-71.

Crum, B. and Fossum, J.E. (eds) (2013) Practices of Inter-Parliamentary Coordination in International Politics: The European Union and Beyond. Colchester: ECPR Press.

European Convention (2002) Summary Report of the Plenary Session. Brussels, 11-12 July 2002.

European Parliament (2011) European Parliament resolution of 7 July 2011 on the European Parliament's approach to implementing Articles 9 and 10 of Protocol 1 to the Lisbon Treaty as regards parliamentary cooperation in the field of CFSP/CSDP. Available from: http://www.europarl.europa.eu/sides/getDoc.do?pubRef=-//EP// TEXT+TA+P7-TA-2011-0337+0+DOC+XML+V0//EN [accessed $21 \mathrm{March}$ 2018].

Fabbrini, S. (2015) Which European Union? Europe after the Euro Crisis. Cambridge: Cambridge University Press.

Fossum, J.E. (2017) Democracy and legitimacy in the EU: challenges and options. In: Vai, L., Tortola, P.D. and Pirozzi N. (eds) Governing Europe: How to Make the EU More Efficient and Democratic. Brussels: Peter Lang.

Genschel, P. and Jachtenfuchs, M. (2014) Beyond the Regulatory Polity? The European Integration of Core State Powers. Oxford: Oxford University Press.

Giegerich, B. and Wallace, W. (2010) Foreign and security policy: civilian power Europe and American leadership. In: Wallace, H., Pollack, M.A. and Young, A. (eds) Policy-Making in the European Union. 6th ed. Oxford: Oxford University Press, pp. 431-57.

Gourlay, C. (2004) Parliamentary accountability and ESDP: the national and the European level. In: Born, H. and Hängii, H. (eds) The 'Double Democratic Deficit': Parliamentary Accountability and the Use of Force under International Auspices. Aldershot: Ashgate.

Herranz-Surrallés, A. (2014) The EU's multilevel parliamentary (battle)field: inter-parliamentary cooperation and conflict in foreign and security policy. West European Politics. 37(5), 957-75.

Hooghe, L. and Marks, G. (2015) Delegation and pooling in international organisations. Review of International Organisations. 10(3), 305-28.

Huff, A. (2015) Executive privilege reaffirmed? Parliamentary scrutiny of the CFSP and CSDP. West European Politics. 38(2), 396-415.

Jančić, D. (2017) TTIP and legislative-executive relations in EU trade policy. West European Politics. 40(1), 202-21. 
Krenzler, H.G. and Pitschas, C. (2001) Progress or stagnation: the Common Commercial Policy after Nice. European Foreign Affairs Review. 6(3), 291-314.

Majone, G. (2005) Dilemmas of European Integration. Oxford: Oxford University Press.

Marschall, S. (2008) Transnational parliamentary assemblies and European security policy. In: Peters, D., Wagner, W. and Deitelhoff, N. (eds) The Parliamentary Control of European Security Policy. Oslo: ARENA, pp. 109-32.

Nicolaïdis, K. and Meunier, S. (2005) The European Union as a trade power. In: Hill, C. and Smith, M. (eds) International Relations and the European Union. Oxford: Oxford University Press.

Peters, D., Wagner, W. and Deitelhoff, N. (2010) Parliaments and European security policy: mapping the parliamentary field. In: Vanhoonacker, S., Djikstra, H. and Maurer, H. (eds) Understanding the Role of Bureaucracy in the European Security and Defence Policy. European Integration online Papers (EIoP). Special Issue 1(14).

Peters, D., Wagner, W. and Glahn, C. (2013) Parliaments at the water's edge: the EU's naval mission Atalanta. In: Crum, B. and Fossum, J.E. (eds) Practices of Inter-Parliamentary Coordination in International Politics: The European Union and Beyond. Colchester: ECPR Press, pp. 105-23.

Roederer-Rynning, C. and Kallestrup, M. (2017) National parliaments and the new contentiousness of trade. Journal of European Integration. 39(7), 811-25.

Rosén, G. (2015) Striving for Influence: The European Parliament in EU Foreign Policy. PhD dissertation. Department of Political Science, University of Oslo.

Rosén, G. (2016) A match made in heaven? Explaining patterns of cooperation between the Commission and the European Parliament. Journal of European Integration. 38(4), 409-24.

Rosén, G. (2017) The impact of norms on political decision-making: how to account for the European Parliament's empowerment in EU external trade policy. Journal of European Public Policy. 24(10), 1450-70.

Sjursen, H. (2011) Not so intergovernmental after all? On democracy and integration in European foreign and security policy. Journal of European Public Policy. 18(8), 1078-95.

Wessels, W. (1997) An ever closer fusion? A dynamic macropolitical view on integration processes. Journal of Common Market Studies. 35(2), 267-99.

Woolcock, S. (2012) European Union Economic Diplomacy: The Role of the EU in External Economic Relations. Farnham: Ashgate.

Wouters, J. and Raube, K. (2012) Seeking CSDP accountability through interparliamentary scrutiny. The International Spectator. 47(4), 149-63. 